\title{
Detection of gaseous pollutants emitted from engine powered by biodiesel and diesel mixtures
}

\author{
A. M. Rocha ${ }^{1}$, M. P. P. Castro ${ }^{1}$, M. S. Sthel ${ }^{1}$, G. A. Mothé ${ }^{1}$, V. H. Pérez ${ }^{2}$, M. G. Silva ${ }^{1}$, H. Vargas ${ }^{1}$ \\ ${ }^{1}$ Laboratório de Ciências Físicas, CCT \\ ${ }^{2}$ Laboratório de Tecnologia dos Alimentos, CCTA \\ Universidade Estadual do Norte Fluminense Darcy Ribeiro \\ Av. Alberto Lamego, 2000 - Campos dos Goytacazes, RJ (Brazil) \\ Phone/Fax number: +5522 27397229, e-mail: sthel@uenf.br
}

\begin{abstract}
.
Nowadays air pollution has been regarded as a serious environmental problem. One of the main generators of air pollution is the transportation, since the gas combustion from various chemical species is emitted mainly in urban transportation, using mainly diesel fuel. The use of renewable fuels is an attractive alternative choice to reduce environmental impacts. Brazil stands out in the current world scene as a major of alternative energy producer. Brazilian government introduced a program that includes blends of biodiesel to diesel in order to reduce the environmental impact caused by air pollution. Therefore, this study aims to evaluate the emission of gaseous pollutants using a diesel engine bench with mixtures of B5, B10, B15, B20, B25 and B50 of biodiesel in diesel. For this type of analysis, the Infrared Analyser was used to detect $\mathrm{CO}_{2}$ in the range of 1.88 to $2.76 \%$, electrochemical sensors were used to detect CO in the range of 1161 to 1485 ppmv and NOx in the range of 213 to $351 \mathrm{ppmv}$.
\end{abstract}

\section{Key words}

Pollutant Gases, Emission, Biodiesel, Electrochemical Sensors, Photoacoustic

\section{Introduction}

Atmospheric pollution is one of the most serious environmental problems today. Phenomena such as acid rain, photochemical smog, ozone layer depletion, global warming and human health problems are directly related to the increase of this form of pollution [1-15]. The increase in greenhouse gases emission is noticed worldwide. Human activities are the main reasons for this increase. The sector of urban and cargo transportations are the major emitters of greenhouse gases, especially because they use diesel as fuel [16].

Diesel is an important fuel used both for public and private transport sector and its use is expected to increase in the near future. However, diesel is one of the largest contributors to environmental pollution problems worldwide and theses problems can get worse, as the number of diesel powered vehicles is increasing significantly.

Biodiesel is a renewable fuel with a potential to reduce greenhouse gas emissions, which makes it a promising fuel. Thus, Brazilian government instituted in 2005 the Law 11097, issued by the Brazilian Biodiesel Program (ANP, 2005) that determines the addition of percentages of biodiesel in diesel form a binary mixture called BXX (in which $\mathrm{XX}$ is the percentage of biodiesel added in the diesel initial volume), and starting in the same year the B2, which was sold in Brazilian gas stations. Since then, biodiesel consumption exceeded 40 billion litters per year [17]. Biodiesel production has considerably grown in Brazil, especially after the mandatory addition of $5 \%$ biodiesel (B5) in diesel from January 1st, 2010 [17]. In 2014, Brazilian government provides for the addition of $10 \%$ of biodiesel to diesel (B10) $[18,19]$.

Brazil was the second largest producer of biodiesel, after Germany [20]. As the main Brazilian oilseed, soybean corresponds to $86.7 \%$ of the biodiesel production in the country [21]. Brazil is a tropical country with a vast territory, intense sunlight, high biodiversity in oil plants, abundant water resources, regular rainfall and advanced agricultural technology. These characteristics ensure economic advantages in the production of biodiesel.

Biodiesel also provides interesting socioeconomic advantages, because its production increases the jobs supply, contributes to the establishment of man in the countryside and does not require technological changes in engines using percentages up to $20 \%$ of biodiesel added to diesel. [22, 23].

In this work, we present a study of gaseous emissions in a bench engine where we simulated binary mixtures (diesel and biodiesel) in the following proportions: B5, B10, B15, B20, B25 and B50. We detected the following 
gases: carbon dioxide $\left(\mathrm{CO}_{2}\right)$, which is a powerful greenhouse gas, carbon monoxide (CO), which is harmful to human health [24-28], as well as a modulator of methane and tropospheric ozone which are important greenhouse gases [29-36] and nitrogen oxides $\left(\mathrm{NO}_{\mathrm{x}}\right)$, which are generators of acid rain, harmful to human health [37-41] and, in the presence of solar radiation, they are considered precursors of tropospheric ozone [42].

Infrared analyser URAS-14 (Hartmann \& Braun) was used to detect carbon dioxide $\left(\mathrm{CO}_{2}\right)$ in our samples. To detect carbon monoxide $(\mathrm{CO})$ and nitrogen oxides $\left(\mathrm{NO}_{\mathrm{x}}\right)$, an electrochemical sensor Tempest 100 (Telegan Gas Monitoring TP20729) was used. In this work, it was possible to detect $\mathrm{CO}_{2}$ in \% range and $\mathrm{CO}$ and $\mathrm{NO}_{\mathrm{x}}$ in ppmv range.

\section{Experimental Section}

The samples were produced by the combustion of binary mixtures (diesel/biodiesel) in Toyama brand engine (6.7 HP, $296 \mathrm{cc}$, with direct injection system and manual start). The engine was kept running for 5 minutes to stabilize, before starting the measurements, in order to standardize them. Two modes of operation of this engine were used in this experiment: low rotation speed $(3000 \mathrm{rpm})$ and high rotation speed (9000 rpm).

The samples were collected due to the pressure difference and stored in a metal container (canister) internally coated with teflon for 2 minutes at room temperature and later, the same gas was sucked by vacuum pump of the collector AVOCS (Graseby) (Sample Canister volatile environment). Then, the samples were removed for analysis of gas, with the photoacoustic analyser (URAS). The same gas was sucked by Tempest via cannula, in which the result could be obtained in real time.

This procedure was adopted to collect the samples of biodiesel blends in diesel B5, B10, B15, B20 and B25 (B5, which means a $5 \%$ blend of biodiesel in diesel fuel, and so on). Measurements began with B5, considered as the Brazilian standard diesel currently, and for this reason, it was not possible to study the diesel without the addition of biodiesel in this paper.

\section{Results and Discussion}

The concentration of carbon dioxide $\left(\mathrm{CO}_{2}\right)$ emitted by the exhaust of a diesel engine working with binary mixtures of soybean biodiesel and diesel oil (B5, B10, B15, B20, B25, B50) is shown in Figure 1, being the errors bar derived from the statistical error of five repetitions using the same parameters. We can observe that the emission of $\mathrm{CO}_{2}$ was reduced when the engine was operated at low speed, especially for the sample B50. We also observed that the emission of gases in high speed rotation mode remained practically constant in all samples. No significant change with the addition of higher biodiesel concentrations could be observed, except for B50, in which the emitted gas was reduced.

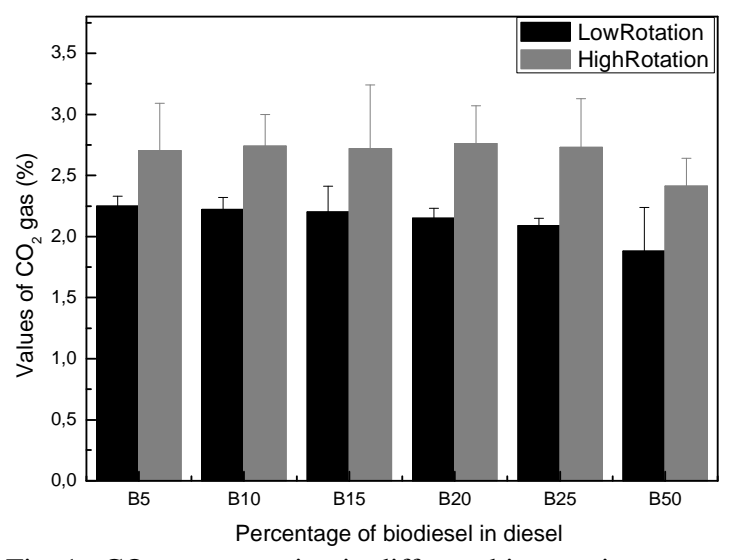

Fig. 1. $\mathrm{CO}_{2}$ concentration in different binary mixture.

As the carbon dioxide gas comes from the complete combustion which was related to the temperature of the gases, when using the engine at high rotation, the temperature was increased, providing the best gas emission that has been observed in the results [43].

Figure 2 shows the obtained carbon monoxide (CO) concentration after combustion in a diesel engine operating on different binary mixtures of soybean biodiesel and diesel oil. Wherein noted that the $\mathrm{CO}$ emission was reduced in both modes of operation (high and low) of the blends B5, B10, B15 and B20. The samples from B25 and B50 showed a different behaviour. This fact may explain why, according to literature, diesel engine requires no modification when using biodiesel up to a concentration of $20 \%$, but higher concentrations have to be used after some changes in engine [44-48]. As we have not changed the engine, our results proved this assertion.

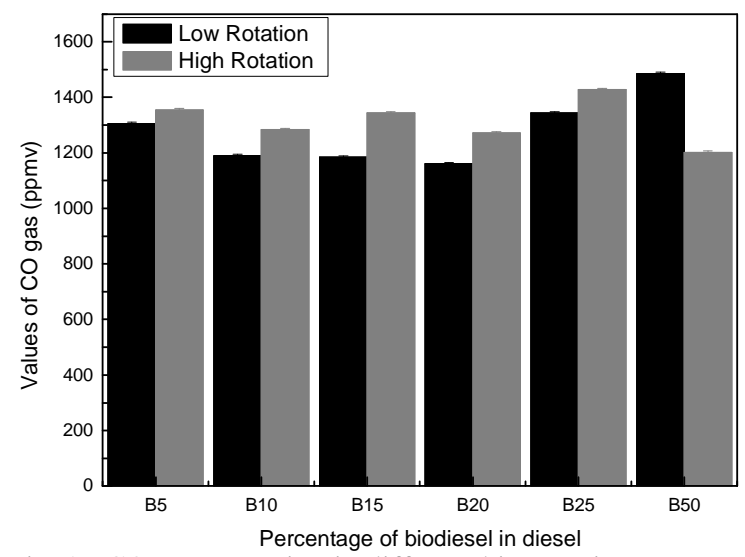

Fig. 2. CO concentration in different binary mixture.

In Figure 2, CO concentration was the lowest in the low speed rotation mode, except for the binary mixture B50. This result was consistent with the work of Mothé (2010) [43] and Ileri and Koçar (2009) [44], who reported that during the operating cycle, the catalytic activity is higher due to increased exhaust temperature, reducing $\mathrm{CO}$ emissions. Almeida (2002) [45] explains that as a greater amount of air provided to increase the rotational speed of the engine, the intensity of turbulence in the combustion chamber is increased, affecting the process air-fuel mixture, resulting in increased rate of complete combustion, thereby reducing $\mathrm{CO}$ emissions. 
The sample B50 shows an anomalous behaviour, which can be explained by the fact that it contain more biodiesel, so it is more viscous and, according to Tulcan (2009) [46], carbon monoxide is produced when the carbon atoms are not completely saturated during the process. Thus, combustion can be influenced by increased viscosity of the biodiesel compared to diesel.

In Figure 3, the concentration of nitrogen oxides $\left(\mathrm{NO}_{\mathrm{x}}\right)$ from the combustion of binary mixtures is presented. Currently, there are many peculiarities in the analysis of $\mathrm{NO}_{\mathrm{x}}$, which may be related to the type of fuel, the fuel quality, the fuel spray characteristics, operating conditions, engine technology, the compression ratio, the geometry of the combustion chamber (related to the propagation speed of the flame), the equivalence air/fuel ratio, pressure and temperature of air injection, the chemical properties of the fuel, and the percentage dissipation gas in ambient air.

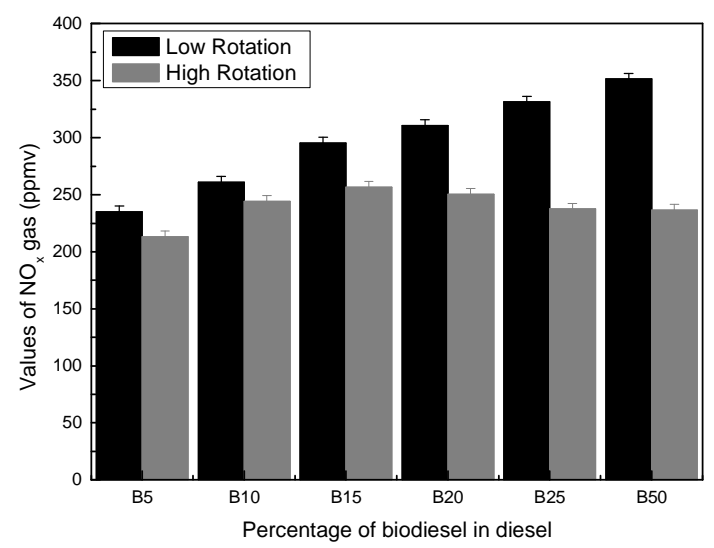

Fig. 3. $\mathrm{NO}_{\mathrm{x}}$ concentration in different binary mixture.

In this work, it can be observed in figure 3 that in low speed rotation mode, $\mathrm{NO}_{\mathrm{x}}$ increases when the concentration of biodiesel increases. This result is consistent with the literature and can be related to the higher cetane number of the biodiesel providing the combustion at higher temperatures. Furthermore, the presence of oxygen in the molecule of biodiesel can also increase the rate of $\mathrm{NO}_{\mathrm{x}}$ formation [49-52].

We could notice that the increasing percentage of biodiesel in the binary mixture promotes environmental improvement, with respect to carbon dioxide gas $\left(\mathrm{CO}_{2}\right)$, the main gas responsible for the greenhouse effect, once it is reduced when the engine runs at lower rotation speeds. Evaluating carbon monoxide (CO) emission, we could notice that the addition of biodiesel in binary mixtures did not result in increased emissions of this gas, which is a modulator of methane, a greenhouse gas.

The addition of biodiesel in the binary mixtures caused an increase of $\mathrm{NO}_{\mathrm{x}}$ emission. This gas is a precursor for the generation of the tropospheric ozone, which is intensified in Brazil, as it is a tropical country with high incidence of solar radiation.

\section{Conclusions}

In this work, the infrared gas analyser and the electrochemical sensors were sensitive and selective to detect polluting gases. It was possible, due to the wide dynamic range of detection of photoacoustic technique and selectivity, to detect different gases with the electrochemical sensors in ppmv range.

We concluded that binary mixtures until B20 do not show an increase in the emission of gases analysed in this paper, at laboratory conditions with a bench motor, in relation to diesel fuel, with the exception of $\mathrm{NO}_{\mathrm{x}}$ gas, although some studies has made vehicle adaptations with the addition of catalysts aiming at reducing the gas enabling improvements population with the biodiesel.

Brazil is a large country, with continental dimensions, where the transport of passengers and cargo is predominantly by road, using diesel, which is a fossil fuel. Thereby, increasing the percentage of biodiesel in binary mixtures can be energetically and environmentally favourable, since biodiesel is a renewable fuel. Brazilian government has a proposal to increase the percentage of biodiesel in binary mixtures, from B10 to B20.

Therefore, there is a great effort to turn the Brazilian transport system into a more sustainable one, through the adoption of governmental programs that stimulate the use of biofuels, such as ethanol and biodiesel, in substitution of fossil fuels, mainly diesel and gasoline.

\section{Acknowledgement}

The authors would like to thank the Brazilian agencies CNPq, FAPERJ and CAPES for their financial support, and the technician Luiz Antônio Meirelles for the great technical help.

\section{References}

[1] Steffen, W.; Sanderson, A.; Jäger, J.; Tyson, P. D.; Moore, B., III; Matson, P. A.; Richardson, K.; Oldfield, F.; Schellnhuber, H. J.; Turner, B. L., II; Wasson, R. J. (2004) Global Change and the Earth System: A Planet under Pressure; Springer-Verlag: Heidelberg, Germany.

[2] IPCC (2007). Climate Change: The Physical Science Basis; Report of Working Group I; IPCC: Paris, France, February.

[3] Hansen, J.; Makiko, S.; Pushker, K.; David, B.; Robert, B.; Valerie, M. D.; Mark, P.; Maureen, R.; Dana, L. R.; James, C. Z. (2008) Target atmosphere $\mathrm{CO}_{2}$ : Where should humanity aim. Open Atmos. Sci. J., 2, 217-231.

[4] Meinshausen, M.; Meinshausen, N.; Hare, W.; Raper, S. C. B.; Frieler, K.; Knutti, R.; Frame, D. J.; Allen, M. R. (2009) Greenhouse gas emission targets for limiting global warning to $2{ }^{\circ} \mathrm{C}$. Nature, $458,1158-1162$.

[5] Hansen, J.; Sato, M. (2004) Greenhouse gas growth rates. Proc. Natl. Acad. Sci. USA, 101, 16109-16114.

[6] Nathan, P.; Gillett, D. A.; Stone, P. A. S.; Toru, N.; Alexey, Y.; Karpechko, G. C.; Heger, M. F. W.; Philip, D. J. (2008) Attribution of polar warming to human influence. Nat. Geosci., 1, 750-754.

[7] Siddall, M.; Stocker, T. F.; Clark, P. U. (2009) Constrains on future sea-level from past sea-level change. Nat. Geosci., 2, 571-575. 
[8] Myles, R. A.; Frame, D. J.; Huntingford, C.; Jones, D. D.; Lowe, J. A.; Meinshausen, M.; Meinshausen, N. (2009) Warning caused by cumulative carbon emissions towards the trillionth tone. Nature, $458,1163-1166$.

[9] Sthel, M. S.; Tavares, J. R.; Lima, G. R.; Mothé, G.; Schramm, D. U. S.; da Silva, M. G.; Castro, M. P. P. (2010) Atmospheric pollution: Global warming and a possible use of bio-fuels wide scale. Int. Rev. Chem. Eng., 1. 564-570.

[10] Rosenzweig, C.; David, K.; Marta, V.; Peter, N.; Qigang, W.; Gino, C.; Annette, M.; Terry, L. R.; Nicole, E.; Bernard, S.; Piotr, T.; Chunzhen, L.; Samuel, R.; Anton, I. (2008) Attributing physical and biological impacts to antropogenic climate change. Nature, 453, 353-358.

[11] Solomon, S.; Plattner, G. K.; Knuttic, R.; Friedlingstein, P. (2009) Irreversible climate change due to carbon dioxide emissions. Proc. Natl. Acad. Sci. USA, 106, 17041709 .

[12] Trenberth, E. K.; Moore, B.; Karl, T. R.; Nobre, C. (2006) Monitoring and prediction of the earth's climate: A future perspective. J. Clim. Spe. Sec., 19, 5001-5008.

[13] Hansen, J.; Nazarenko, L. (2004) Soot climate forcing via snow and ice albedos. Proc. Natl. Acad. Sci. USA, 101, 423428.

[14] Hansen, J.; Nazarenko, L.; Ruedy, R.; Sato, M.; Willis, J.; Del Genio, A.; Koch, D.; Lacis, A.; Lo, K.; Menon, S.; Novakov, T.; Perlwitz, J.; Russell, G.; Schmidt, G.A.; Tausnev, N. (2005) Earth's energy imbalance: Confirmation and implications. Science, 308, 1431-1435.

[15] Michael, E. M.; Bradley, R. S.; Hughest, M. K. (1998) Global temperature patterns and climate forcing over the past six centuries. Nature, 392, 779-787.

[16] http://www.eia.gov/tools/faqs/faq.cfm?id=307\&t=11(ac cessed 25 august 2013).

[17] Fontana, J. D.; Vedana U. (2010) Biodiesel: para leitores de 9 a 90 anos editora UTFPR ed., ISBN 9788573352436.

[18] www.celuloseonline.com.br (accessed 6 august 2012).

[19] Indústrias de biodiesel apostam em mistura de 7\% já em 2013. www.exame.abril.com.br (accessed 6 august 2012).

[20] U.S. ENERGY

INFORMATION

ADMINISTRATION.International Energy Statistics:

Renewables, 2011. Available on line: 205.254.135.7/cfapps/ipdbproject, (accessed 20 january 2012).

[21] Filho, A. K. D. B.; Barroso, W. M.; Rodrigues, A. C. C.; Das Neves, L. P. (2011) Agência Nacional do Petróleo, Gás Natural e Biocombustíveis (ANP), Superintendência de Refino e Processamento de gás natural - SRP, Boletim mensal de biodiesel, agosto

[22] Ramos, L. P.; Domingos, A. K.; Kucek, K. T.; Wilhelm, H. M. (2003) Biodiesel: Um projeto de sustentabilidade econômica e sócio-ambiental para o Brasil. Biotecnologia: Ciência e Desenvolvimento, 31, 28-37

[23] Geller, D.P.; Goodrum, J. W. (2004) Effects of specific fatty acid methyl esters on diesel fuel lubricity. Fuel; 83, 17-18, 2351-2356.

[24] Maitre, A.; Bonneterre, V.; Huillard, L.; Sabatier, P.; Gaudemaris, R. (2006) Impact of urban atmospheric pollution on coronary disease. Eur. Heat J., 27, 2275-2284.

[25] Townsend, C.; Maynard, R. (2002) Effects on health of prolonged exposure to low concentrations of carbon monoxide. Occup. Environ. Med., 59, 708-711.

[26] Favory, R.; Lancel, S.; Tissier, S.; Mathieu, D. (2006) Myocardial dysfunction and potential cardiac hypoxia in rats Induced by carbon monoxide inhalation. Amer. J. Res. Crit. Car. Med., 174, 320-325.

[27] Lindell, K. W.; Ramona, O. H.; Karen, J. C.; Susan, C.; Gregory, E.; Terry, P.; James, F.; Frank, O.; Alan, H. (2009) Carbon monoxide poisoning. New Eng. J. Med., 360, 1217-1225.

[28] Brook, R. D.; Franklin, M.; Cascio, W.; Hong, Y.; Howard, G.; Lipsett, M.; Luepker, R.; Mittleman, M. (2004) Air pollution and cardiovascular disease. J. Amer. Heart Assoc., $109,2655-2671$.

[29] US Environmental Production Agency (2010). Carbon monoxide health and environmental impacts of CO. Available online: http://www.epa.gov/air/urbanair/co/hlth1.html (Accessed on October 29, 2010).

[30] Lijie, G.; Meigen, Z.; Zhiwei, H. (2009) Model analysis of seasonal variations in tropospheric ozone and carbon monoxide over East Asia. Adv. Atmos. Sci., 26, 312-318.

[31] Latha, M. K.; Badarinath, K. V. S. (2004) Correlation between black carbon aerosols, carbon monoxide and tropospheric ozone over a tropical urban site. Atmos. Res., 71, 265-274.

[32] Seinfeld, J. H.; Pandis, S. N. (2006) Atmospheric Chemistry and Physics - From Air Pollution to Climate Change, 2nd ed.; Wiley-Interscience: Malden, MA, USA.

[33] Ray, N.; Jennifer, A.; Logan, I.; Megretskaia, A.; Lee, T.; Murray, D.; Jones, B. A. (2009) Analysis of tropical tropospheric ozone, carbon monoxide, and water vapor during the 2006 El ninho using Tes observations and the Geos- Chem model. J. Geoph. Res. Atmos., 114, 23-25.

[34] National Oceanic and Atmospheric Administration National Climatic Data Center (2010). Greenhouse gases frequently asked questions. Available on line: http://www.ncdc.noaa.gov/oa/climate/ gases.html (accessed on 29 October 2010).

[35] Brook, R. D.; Franklin, M.; Cascio, W.; Hong, Y.; Howard, G.; Lipsett, M.; Luepker, R.; Mittleman, M. (2004) Air pollution and cardiovascular disease. J. Amer. Heart Assoc., 109, 2655-2671

[36] MgGonigle, A. J. S.; Hilton, A. J. S.; Fischer, D. R. (2004) A simple technique for measuring power station $\mathrm{SO}_{2}$ and $\mathrm{NO}_{2}$ emissions. Atmos. Environ., 38, 21-25.

[37] Ramadour, M.; Burel, C.; Lanteaume, A.; Vervloet, D.; Charpin, D.; Brisse, F.; Dutau, H.; Charpin, D. (2000) Prevalence of asthma and rhinitis in relation to long-term exposure to gaseous air pollutants. Allergy, 55, 1163-1169.

[38] Lee, Y-L.; Shaw, C. K.; Su, H. J. (2003) Climate, traffic-related air pollutants and allergic rhinitis prevalence in middle-school children in Taiwan. Eur. Respir. J., 21, 964-970.

[39] Seinfeld, J. H. (1986) Atmospheric Chemistry and Physics of Air Pollution; John Wiley \& Sons: Hoboken, NJ, USA.

[40] Rocha, A.; Sthel, M.; Castro, M.; Peres, V.; Mothe, G.; Brasil, L.; Vargas, H. (2012) Detection of Ethylene Emitted by Diesel-biodiesel Engine Using $\mathrm{CO}_{2}$ Laser Photoacoustic Sensors. Applied Physics Research, 4, 3, 16-21.

[41] Conselho Nacional do Meio Ambiente (CONAMA) $\mathrm{N}^{\circ}$. 10, 09/14/1989. Retrieved from http://www.mma.gov.br/port/conama/res/res89/res1089.html

[42] Baird, C. (2002) Environmental Chemistry, 2nd ed.; Brookman: Porto Alegre, Brazil.

[43] Mothe, G.; Castro, M. P.; Sthel, M. S.; Lima, G. R.; Campos, L.; Brasil, L. R.; Rocha, A. M.; Vargas, H. (2010) Detection of greenhouse gas precursors from diesel engines using electrochemical and photoacoustic sensors. Sensors, 10, 9726-9741.

[44] . Ileri, E.; Koçar, G. (2009) Experimental investigation of the effect of fuel injection advance on engine performance and exhaust emission parameters using canola oil methyl ester in a turbocharged direct-injection diesel engine. Energy Fuels, 23, 5191-5198.

[45] Almeida, S. C. A.; Belchiora, C. R.; Nascimento, B. M. V. G.; Vieira, B.; Fleury, B. G. (2002) FUEL, 81, 2097 2102. APUD Ileri, E.; Koçar, G. (2009) Experimental Investigation of the Effect of Fuel Injection Advance on Engine Performance and Exhaust Emission Parameters Using Canola Oil Methyl Ester in a Turbocharged Direct-Injection Diesel Engine. Energy Fuels, 23, 5191-5198. 
[46] Tulcan, O. E. P. (2009) Estudo do desempenho do grupo motor-gerador alimentado com diferentes misturas dieselbiocombustível e avaliação de emissões. Tese apresentada ao Curso de Pós-Graduação em Engenharia Mecânica da Universidade Federal Fluminense, Niterói.

[47] Mccormick, R. L.; Graboski, M. S.; Alleman, T. L.; Herring, A. M.; Tyson, K. S. (2001) Impact of biodiesel source material and chemical structure on emissions of criteria pollutants from a heavy-duty engine. Environ. Sci. Technol., 35, 1742-1747.

[48] Karavalakis, G.; Bakeas, E.; Stournas, S. (2010) Influence of Oxidized Biodiesel Blends on Regulated and Unregulated Emissions from a Diesel Passenger Car. Environ. Sci. Technol., 44, 5306-5312.

[49] Seinfeld, J. H. (1989) Urban air pollution: State of the science. Science, 243, 745-752.

[50] Lefohn, S.; Foley, J. K. (1993) Establishing relevant ozone standards to protect vegetation and human health: exposure/dose-response considerations. J. Air Waste Manage. Assoc., 43, 106-112.

[51] Atkinson, R. (2000)Atmospheric chemistry of VOCs and $\mathrm{NO}_{\mathrm{x}}$. Atmosph. Environ., 34, 2063-2101.

[52] Wolf, G. T.; Korsog, P. E. (1992) Ozone control strategies based on the ratio of volatile organic compound to nitrogen oxides. J. Air Waste Manage. Assoc., 42, 1173-1177. 